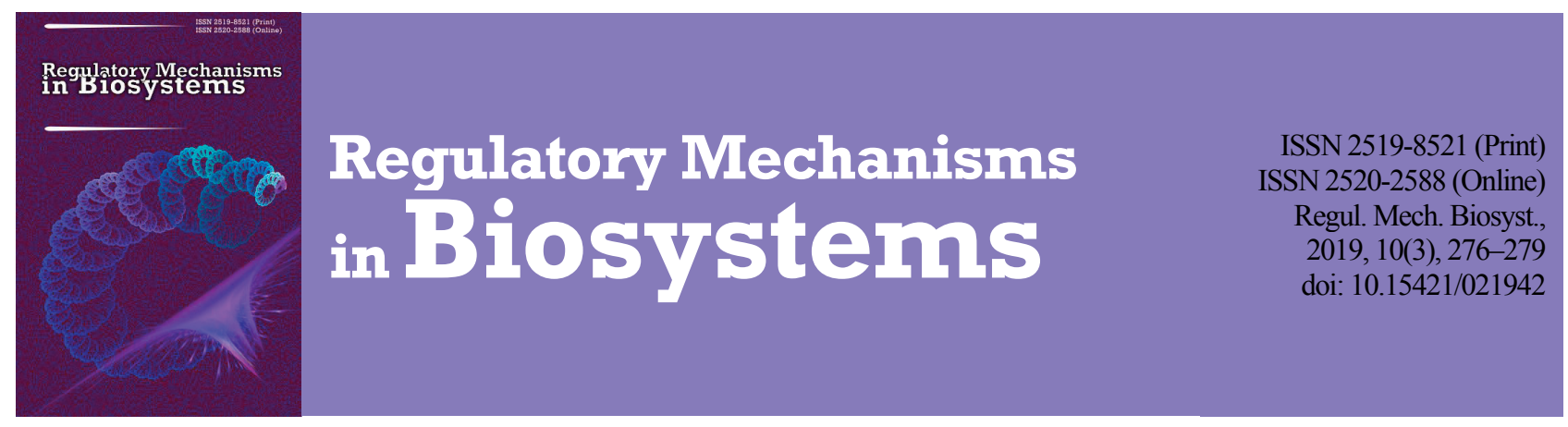

\title{
Acute toxicity of the iron clathrochelate complexes
}

\author{
V. Dukhnitsky*, I. Derkach*, M. Plutenko**, I. Fritsky**, S. Derkach* \\ *National University of Life and Environmental Sciences of Ukraine, Kyiv, Ukraine \\ **Taras Shevchenko National University of Kyiv, Kyiv, Ukraine
}

Article info

Received 07.06.2019

Received in revised form 03.07.2019

Accepted 05.07.2019

The National University of Life and Environmental Sciences

of Ukraine, Heroyiv

Oborony st., 15

Kyiv, 03041, Ukraine.

$\mathrm{Tel} \cdot+38-066-772-41-94$

E-mail:

irina1215@ukr.net

Taras Shevchenko

National University

of Kyiv, Volodymyrska st

64 Kyiv, 01601, Ukraine.

Tel.: +38-097-060-82-98.

E-mail:

plutenkom@gmail.com

\section{Dukhnitsky, V., Derkach, I., Plutenko, M., Fritsky, I., \& Derkach, S. (2019). Acute toxicity of the iron clathrochelate complexes. Regulatory Mechanisms in Biosystems, 10(3), 276-279. doi:10.15421/021942}

A new class of highly valent iron compounds is formed by atmospheric oxidation in aqueous media and it is extremely stable both in solid and soluble conditions and may exist indefinitely in a medium without signs of degradation. The first clathrochelate complexes of iron (IV) are infinitely stable in water and readily available from simple, commercially available, inexpensive source materials with surprisingly mild reaction conditions. To create new drugs on their bases, research on their toxicity is required. In this study, the results of preclinical studies of a new iron clathrochelates drug are presented. Experiments were carried out on white rats and quails, which in the previous experiment were divided into five experimental and two control groups. The solution of iron clathrochelate complexes was administered intragastrically in doses $50,500,1000,2000$ and $5000 \mathrm{mg} / \mathrm{kg}$, respectively. Our results have shown that there were no grounds for using rats in the advanced experiment because the conducted research has established that iron clathrochelate is non toxic to rats. Thus, the minimum dose of iron clathrochelate complexes did not cause death of quails, and the largest dose caused $100 \%$ mortality. The basic experiment was conducted on 6 groups of birds, each consisting of 7 quails. The drug was administered in the following doses: $500,600,700,800,900,1000 \mathrm{mg} / \mathrm{kg}$. The monitoring observation of the laboratory birds lasted for 14 days. It has been established that the average lethal dose of clathrochelate of the investigated drug for internal administration in quails is $764 \pm 33 \mathrm{mg} / \mathrm{kg}$. According to the classification of chemicals by the degree of danger (State ST 12.1.007-76), iron (IV) clathrochelate complexes correspond to the third class of hazard, and according to the classification of substances for toxicity they are classified as category 4 (low toxicity substances). The prospect of further research is to investigate the pharmacological and toxicological properties of iron (IV) clathrochelate for chronic toxicity.

Keywords: toxicology; preclinical studies; average lethal dose; iron (IV); rats; quails.

\section{Introduction}

Uncontrolled usage of medicines causes an increase in toxic effects in human and animal organisms (Gutyj et al., 2017). In accordance with the guidelines for the preclinical study of drugs, every new drug must be evaluated for the following indicators: the toxicity of the bioassay to infusoria; the toxicity in laboratory animals after a single administration (acute toxicity); the cumulative properties; the toxicity in laboratory animals after long-term administration (chronic toxicity). In our previous studies (Dukhnitsky et al., 2018) we found that the average lethal dose of iron (IV) clathrochelates for white mice following intragastric administration is $1258 \pm 145 \mathrm{mg} / \mathrm{kg}$. According to the classification of chemicals by the degree of danger (State ST 12.1.007-76), iron (IV) clathrochelates complexes correspond to the third class of hazard, and according to the classification of substances for toxicity they are classified as toxic category 4 (low toxicity substances).

At present, knowledge about the value of iron for metabolic processes (Bonkovsky \& Herbert, 1991; Ganz, 2013; Dos Santos Vieira et al., 2018) and its use in combination with other substances, such as vitamins (Diel et al., 2018; Pillay et al., 2018), microelements (Todoriuk et al., 2018; Terpilowska \& Siwicki, 2018, 2019) or in the form of nanocrystals (Zheng et al., 2008) for different routes of the administration (Maes et al., 2011; Peña-Rosas et al., 2015; Stephanyk et al., 2017) is deepened. This is relevant in connection with the worldwide registration of iron deficiency anemia (Batrakov, 2005; Killip \& Bennett, 2008; Dela Cruz-Góngora, 2018), sometimes in combination with diabetes (Broide, 2018; Miranda, 2018) or other diseases (Yeh et al., 2019). Analyzing the literature data on corresponding topics, we also noticed that within an in-depth study of the properties of the bivalent iron (II) and the trivalent iron (III) (Jiefen et al., 2017), the study of high-valent iron (IV, V, VI) becomes very relevant. In the field of chemistry, researchers focus their attention on the analysis of the stability of ultra-stable oxoiron (IV) complexes (England et al., 2014), their reactivity in catalytic processes (Tang, 2016). Particular attention is paid to the study of the system based on the class of tetraamide macrocyclic ligands Fe-TAML (Collins, 2002; Tang et al., 2015). Investigating various aspects of the reactivity of iron (IV) in chemical and biological systems, Groves (2006) found that oxoferiline-cation $[\mathrm{FeIVO}]^{2+}$ can be formed under different conditions, in particular in the $\mathrm{Fe}^{2+}-\mathrm{H}_{2} \mathrm{O}_{2}$ system, known as Fenton's reagent.

Along with the use of iron compounds of various valencies as model compounds for the modeling of enzyme active centers and as universal catalysts, preclinical and clinical studies of iron-containing drugs are carried out on laboratory animals (Streyl et al., 2015; Jiefen et al., 2017; Todoriuk et al., 2018). On the other hand, the literature data of recent years have shown structure/histotoxicity relationship of iron preparations (Geisser, 1992). There are also numerous general reviews of the market for pharmaceutical products containing it (Kalinowska, 2014; Derkach, 2017; Derkach et al., 2018).

Frysky et al. (2017) reported a new class of high-valent iron compounds, formed by atmospheric oxidation in aqueous media, that are extremely stable in both the solid and soluble states, and that can exist indefinitely under ambient conditions, exhibiting no signs of degradation. The exceptionally efficient stabilization of the iron (IV) oxidation state can be attributed to the highly (6-) negative charge of the clathrochelate ligand combined with a strong electron-donor effect from the six depro- 
tonated hydrazide nitrogen atoms, as well as a shielding effect provided by the macropolycyclic cage on the metal ion. The observed enormous aqueous stability clearly distinguishes the presented iron (IV) complexes from most of the earlier reported high-valent iron compounds that are typically unstable, highly reactive and quickly decomposing species in aqueous media.

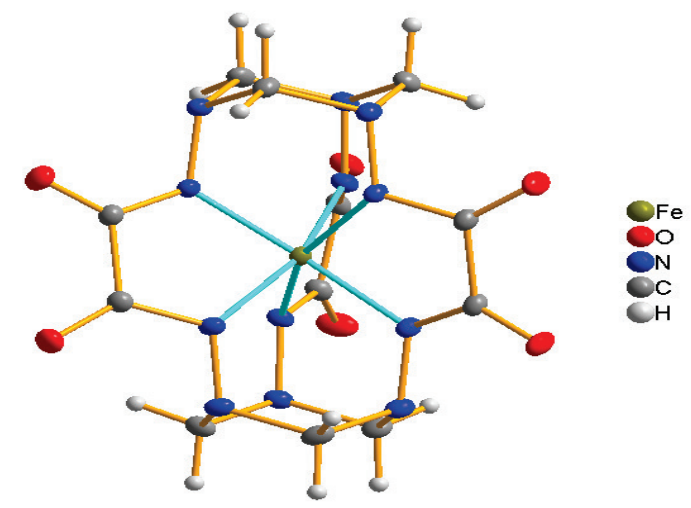

Fig. 1. Chemical structure of clathrochelate anion $[\mathrm{Fe}(\mathrm{L}-6 \mathrm{H})] 2^{-}$

These are the first high-valent iron complexes indefinitely stable in water. Moreover, they are stable at least for weeks under aggressive (strongly acidic or basic) conditions. The results showed that novel iron (IV) complexes are readily accessible from simple, commercially available, inexpensive starting materials under surprisingly mild reaction conditions.

The purpose of the study was to determine the toxicological properties of iron (IV) clathrochelate $\mathrm{Na}_{2}[\mathrm{Fe}(\mathrm{L}-6 \mathrm{H})] \cdot 2 \mathrm{H}_{2} \mathrm{O}$ for single intragastric administration in laboratory animals (rats and quails).

\section{Material and methods}

Synthesis of $\mathrm{Na}_{2}[\mathrm{Fe}(\mathrm{L}-6 \mathrm{H})] \cdot 2 \mathrm{H}_{2} \mathrm{O} .3 .24 \mathrm{~g}$ of $\mathrm{FeCl}_{3} \cdot 6 \mathrm{H}_{2} \mathrm{O}(12 \mathrm{mmol})$ were dissolved in $20 \mathrm{~mL}$ of water and mixed with $42 \mathrm{~mL}$ of $1 \mathrm{M} \mathrm{NaOH}$ solution ( $42 \mathrm{mmol}$ ). The resulting iron (III) hydroxide was filtered off, washed with water and added to the warm $\left(\sim 70^{\circ} \mathrm{C}\right)$ solution of oxalodihydrazide ( $4.248 \mathrm{~g}, 36 \mathrm{mmol})$ in $360 \mathrm{~mL}$ of water. Then $26 \mathrm{~mL}$ of $1 \mathrm{M}$ $\mathrm{NaOH}$ solution and excess quantities of an aqueous formaldehyde solution $(37 \%$ in water, $18 \mathrm{~mL}, 22.2 \mathrm{mmol})$ were added and the resulting reaction mixture was stirred for 2 hours at slight heating $\left(\sim 40^{\circ} \mathrm{C}\right)$. The resulting dark green mixture was filtered off and the solvent was removed on a rotary evaporator. The obtained dark green precipitate was dissolved in $50 \mathrm{~mL}$ of warm $\left(70{ }^{\circ} \mathrm{C}\right)$ water and $150 \mathrm{~mL}$ of ethanol was slowly added with stirring. The resulting dark green powder was filtered off, air dried and double recrystallized from water. The output was $0.795 \mathrm{~g}(11.9 \%)$. Elemental analysis for $\mathrm{C}_{12} \mathrm{H}_{16} \mathrm{~N}_{12} \mathrm{O}_{8} \mathrm{Na}_{2} \mathrm{Fe}$ calculated (\%): C, 25.82; H, 2.89; N, 30.11. Found, \%: C, 25.97; H, 3.03; N, 29.92. ESI-MS, m/z: $477\left[\mathrm{M}^{+} \mathrm{H}^{\dagger}\right], 499\left[\mathrm{M}^{+} \mathrm{Na}^{+}\right]^{-}$. IR, v/cm: 3418, $1642,1612,1431,1392,1385,1300,1202,1175,1112,1095,1030$, $996,948,918,897,745,659,638,455,437$.

To study the acute toxicity of iron (IV) clathrochelate complexes experiments were performed on 18 rats, 3.5-4.0-months of age, weighing 180-200 $\mathrm{g}$ and 67 quails, 6-7-weeks of age, weighing 190-210 g.

Housing, feeding, looking after and all other manipulations with animals were done according to the European Convention for the Protection of Vertebrate Animals used for Experimental and Other Scientific Purposes (Strasbourg, 1986) and General Ethical Principles of Experiments on Animals, adopted by the First National Bioethics Congress (Kyiv, 2001). The experiments were conducted in accordance with the principles of humanity set out in the Directive of the European Community.

Experimental studies were conducted under vivarium conditions at the Department of Pharmacology and Toxicology of the Faculty of Veterinary Medicine of the National University of Life and Environmental Sciences of Ukraine. The research object was iron (IV) clathrochelate complexes $\mathrm{Na}_{2}[\mathrm{Fe}(\mathrm{L}-6 \mathrm{H})] \cdot 2 \mathrm{H}_{2} \mathrm{O}$ (where $\mathrm{L}$ is a macrobicyclic hexahydrazide ligand), which were synthesized at the Department of Physical Chemistry of the Taras Shevchenko National University of Kyiv.
Acute toxicity parameters of iron (IV) clathrochelate complexes were determined according to the methods of Kosenko et al. (1997), Kocjumbas (2006). Rats and quails were kept in quarantine for 14 days before conducting the research; they had free access to feed and water. Feeding and drinking were stopped 3 hours prior to administration of the investigated substance.

Determination of the dose range for the main experiment was carried out in the previous experiment. For this purpose, based on the principle of analogues, the rats/quails were divided into five experimental groups with three rats/quails in each. The solution of iron (IV) clathrochelate complexes was administered intragastrically at doses 50, 500, 1000,2000 and $5000 \mathrm{mg} / \mathrm{kg}$ of body weight, respectively.

Since death occurred only among quails, an advanced experiment was conducted thereafter. Thus, the minimum dose of iron (IV) clatrochelate complexes did not cause death of quails, and the largest dose caused $100 \%$ mortality.

The main experiment was conducted on 6 groups of birds, 7 quails in each. The drug was administrated at the following doses: 500, 600, $700,800,900,1000 \mathrm{mg} / \mathrm{kg}$ of body weight of birds. There were no grounds for using rats in the advanced experiment.

Three control groups were also formed (two groups for the previous experiment (rats, quails, $\mathrm{n}=3$ ), one group of quails for the main experiment $(n=7))$. Rats and quails in the control groups were injected with distilled water in a volume not exceeding $4-5 \mathrm{~mL}$. The monitoring examination of the laboratory birds lasted for 14 days. On the first day of the experiment, the animals were under constant surveillance. Then we took into account the following indicators: general condition, appearance, birds' behaviour, intensity and nature of the mobile activity, presence of convulsions, coordination, response to external stimuli (tactile, sound, light), the condition of the feathers, visible mucous membranes, reaction to food, rhythm, respiratory rate, time of occurrence and nature of intoxication, its severity, course, the death or recovery of the animals.

The average dose $\left(\mathrm{LD}_{50}\right)$ of the dosage form was calculated by the methods of G. Koerber (1931) and G. Pershyn (1939, 1950).

$$
\mathrm{LD}_{50}=\mathrm{LD}_{100}-\Sigma \mathrm{zd} / \mathrm{m} \text {, }
$$

where $\mathrm{LD}_{100}$ - the dose of the substance being studied and causing the death of all birds in the group; $\mathrm{d}$ - the interval between each of the two contiguous doses; $\mathrm{z}$ - arithmetic mean of number of birds killed due to two contiguous doses; $m-$ the number of birds in each group.

$$
\mathrm{LD}_{50}=\Sigma[(\mathrm{a}+\mathrm{b})(\mathrm{m}-\mathrm{n})] / 200,
$$

where $\mathrm{a}$ and $\mathrm{b}$ - the values of adjacent doses; $\mathrm{m}$ and $\mathrm{n}-$ the rates of mortality corresponding to these doses.

Confidential limits were found by the method of K. Miller and M. Tainter. So, $\sigma, \mathrm{m}$ was calculated using the formula:

$$
2 \sigma=\mathrm{LD}_{84}-\mathrm{LD}_{16}
$$

According to the results, iron (IV) clathrochelate was classified according to the degree of danger and toxicity (Kocjumbas, 2006).

\section{Results}

Setting the acute toxicity of the iron (IV) clathrochelate for intragastric administration in rats. In the first minutes after the intragastric administration of solution of iron (IV) clathrochelate solution in rats of all groups, we observed a stressful reaction to the intervention. We noticed a little excitement with subsequent reassurance.

All animals of the experimental groups, who were given a solution of iron (IV) clathrochelate at doses of 50, 500, 1000, 2000 and $5000 \mathrm{mg} / \mathrm{kg}$ of body weight, remained alive. They only showed weakly expressed symptoms of inhibition during the first two hours, which subsequently disappeared and the behaviour of the animals, consumption of feed and water did not differ from the rats of the control group.

The toxic effect of iron (IV) clatrochelate for intragastric administration in rats was not manifested. So, we can assert that the test substance is nontoxic to laboratory animals of this species and, accordingly, conducting the main test for the determination of $\mathrm{LD}_{50}$ was not appropriate.

Setting the acute toxicity of the iron (IV) clathrochelate for intragastric administration in quails. In our previous experiment, a range of doses was established in which the minimum dose of iron (IV) clatrochelate did not cause death of quails, and the largest dose caused $100 \%$ 
mortality. Thus, in the main experiment quails were administered a solution of iron (IV) clatrochelate at doses of 500, 600, 700, 800, 900 and $1000 \mathrm{mg} / \mathrm{kg}$. In the quails of all groups in the first minutes after administration, there was a stressful reaction to the intervention. We noticed a little excitement with subsequent reassurance. In 3-4 hours after administration, birds of the first experimental group were active, responded well to external stimuli, actively consumed food and water. Quails did not differ from those in the control group.

The death of birds was observed in the 2-6th groups during the first 8 days after the administration of the drug (Table 1 ). The clinical symptoms of poisoning involved the increasing depression of quails with the transition to a coma, refusal of food and water consumption, violation of coordination of movement, throwing of the head onto the back, lying on one side and diarrhea.

\section{Table 1}

The protocol of the results of an acute experiment for the intragastric administration of iron (IV) clathrochelate in quails

\begin{tabular}{|c|c|c|c|c|c|c|c|}
\hline \multirow{3}{*}{$\begin{array}{l}\text { Drug, } \\
\mathrm{mg} / \mathrm{kg}\end{array}$} & \multirow{3}{*}{$\begin{array}{l}\text { Number } \\
\text { quail in } \\
\text { group }\end{array}$} & \multicolumn{6}{|c|}{ Number of dead quails } \\
\hline & & \multicolumn{4}{|c|}{ By days } & \multirow{2}{*}{ Total } & \multirow{2}{*}{$\%$} \\
\hline & & 1 & 2 & 8 & 15 & & \\
\hline 500 & 7 & - & - & - & - & 0 & 0 \\
\hline 600 & 7 & - & 1 & - & - & 1 & 14 \\
\hline 700 & 7 & 1 & 1 & - & - & 2 & 29 \\
\hline 800 & 7 & 2 & 1 & 1 & - & 4 & 57 \\
\hline 900 & 7 & 2 & 2 & 2 & - & 6 & 86 \\
\hline 1000 & 7 & 3 & 2 & 2 & - & 7 & 100 \\
\hline
\end{tabular}

During the first three hours in the birds of the experimental groups II-VI administered (iron (IV) clathrochelate at the doses of 600, 700, $800,900,1000 \mathrm{mg} / \mathrm{kg}$ ) there were symptoms of the effect of the drug. We observed oppression, more pronounced in the birds of the groups $\mathrm{V}$ and VI, the abandonment of feed. Quails were sitting in one place. Because of the actions of external stimuli, they tried to get up, but the coordination of the movement was broken: some individuals fell to the side, turned over onto their backs. During the first days of the experiment, birds in these groups suffered oppression, which grew, the quails threw their head back, lay on their side, abandoned feed and water. The faeces were white, watery with bubbles of gas. On the first day, the death of one bird in the third group given (iron (IV) clathrochelate at a dose of $700 \mathrm{mg} / \mathrm{kg}$ ) was established, two - in groups IV and V given (iron (IV) clathrochelate at the doses of 800 and $900 \mathrm{mg} / \mathrm{kg}$, respectively), and three - in group VI given (iron (IV) clathrochelate at a dose of $1000 \mathrm{mg} / \mathrm{kg}$ ). In group II given (iron (IV) clathrochelate at a dose of 600 $\mathrm{mg} / \mathrm{kg}$ ), the death of one bird was recorded on the second day.

Clinical status of the birds of the groups II and III receiving iron (IV) clathrochelate at doses of 600 and $700 \mathrm{mg} / \mathrm{kg}$, respectively was completely restored to normal on the 8-9th day, and in quail in groups IV-V receiving (iron (IV) clathrochelate at doses of 800 and $900 \mathrm{mg} / \mathrm{kg}$, respectively) on the 14-15th day. This gives us the opportunity to assume that there is a functional cumulation of the iron (IV) as a representative of a group of heavy metals. After day 8 th of the experiment, we did not observe the death of the quails.

From the data presented in Table 1, it is seen that the toxic effect of iron (IV) clatrochelate after intragastric administration in quails appears at a dose of 600 and more $\mathrm{mg} / \mathrm{kg}$. Under such conditions, the death of quails in experimental groups ranged from one to seven individuals. Thus, we have the opportunity to make calculations for the definition of $\mathrm{LD}_{50}$.

The research data and calculation $\mathrm{LD}_{50}$ drug are represented in Table 2. So, $\mathrm{m}=7 ; \mathrm{LD}_{100}=1000 \mathrm{mg} / \mathrm{kg} ; \Sigma \mathrm{zd}=50+150+300+500+$ $650=1650$. Thus, $L_{50}=1000-1650 / 7=764.3 \mathrm{mg} / \mathrm{kg}$.

\section{Table 2}

Average lethal dose of iron (IV) clathrochelate following intragasric administration in quails after calculation by the method of G. Koerber

\begin{tabular}{lccccccc}
\hline Drug, mg/kg & 500 & 600 & 700 & 800 & 900 & 1000 \\
\hline Survivors & 7 & 6 & 5 & 3 & 1 & 0 \\
Died & 0 & & 1 & 2 & 4 & 6 & 7 \\
z & & 0.5 & & 1.5 & 3.0 & 5.0 & 6.5 \\
$\mathrm{~d}$ & & 100 & & 100 & 100 & 100 & 100 \\
zd & 50 & 150 & 300 & 500 & 650 & \\
\hline
\end{tabular}

The same data were calculated by the method of G. Pershyn (Table 3 ). So, $[(\mathrm{a}+\mathrm{b})(\mathrm{m}+\mathrm{n})]=15400+19500+42000+49300+26600=$ 152800 . Thus, $\mathrm{LD}_{50}=152800 / 200=764.0 \mathrm{mg} / \mathrm{kg}$.

Table 3

Average lethal dose of iron (IV) clathrochelate following intragastric administration in quails after calculation by the method of G. Pershyn

\begin{tabular}{lcccccc}
\hline Drug, mg/kg & 500 & 600 & 700 & 800 & 900 & 1000 \\
\hline Observed results & $0 / 7$ & $1 / 6$ & $2 / 5$ & $4 / 3$ & $6 / 1$ & $7 / 0$ \\
Percentage of killed birds & 0 & 14 & 29 & 57 & 86 & 100 \\
$\mathrm{a}+\mathrm{b}$ & 1100 & 1300 & 1500 & 1700 & 1900 \\
$\mathrm{~m}-\mathrm{n}$ & 14 & 15 & 28 & 29 & 14 \\
$(\mathrm{a}+\mathrm{b})(\mathrm{m}-\mathrm{n})$ & 15400 & 19500 & 42000 & 49300 & 26600 \\
\hline
\end{tabular}

It should be noted that the results of $\mathrm{LD}_{50}$, which we counted by different methods, were almost unchanged. We found the confidence limits of $\mathrm{LD}_{50}$ by the method of $\mathrm{K}$. Miller and $\mathrm{M}$. Tainter, where we count $\sigma, \mathrm{m}$. According to our data, $2 \sigma=898-653.2=244.8$, on this $\mathrm{m}=32.71$. Thus, $\mathrm{LD}_{50}=764.3 \pm 32.71$.

\section{Discussion}

Worldwide, the development and introduction of new iron-containing compounds for the timely carrying out of preventive measures is one of the main tasks in the fight against anemia (Meier et al., 2011; Jiefen et al., 2017; Kim et al., 2018). Also this illness is diagnosed by iron deficiency in combination with other pathologies, for example diabetes (Walter et al., 1998; Shirinova, 2005; Broide et al., 2018). Therefore, the relevance of the study of new complexes of the iron of various valences, which are synthesized in the field of chemistry, is not lost. In this context, one of the promising groups of the compounds of ferrum is the socalled clathrochelasts, or macrobicyclic complexes.

Accoring to the data of study of the new class of high-valent iron compounds, they formed by atmospheric oxidation in aqueous media and extremely stable in both the solid and soluble states, and it is established that they can exist indefinitely under ambient conditions, exhibiting no signs of degradation. In their research the authors (Tomyn et al., 2017) found the first iron (IV) clathrochelate complexes indefinitely stable in water. Moreover, they were stable at least for weeks under aggressive (strongly acidic or basic) conditions. The results showed that novel iron (IV) complexes are readily accessible from simple, commercially available, inexpensive starting materials under surprisingly mild reaction conditions.

To create new drugs on their bases, research on their toxicity is required. No one in the world has studied toxicity of iron (IV) clatrochelate complexes. Previously, we had conducted studies on their acute toxicity on rodents. In particular, we found that the average lethal dose of iron (IV) clathrochelate for white mice following intragastric administration is $1258 \pm 145 \mathrm{mg} / \mathrm{kg}$. According to the classification of chemicals by the degree of danger (State ST 12.1.007-76), that of iron (IV) clathrochelate complexes corresponds to the third class of hazard, and according to the classification of substances for toxicity they are classified as category 4 (low toxicity substances) (Dukhnitsky et al., 2018).

Acute toxicity of new substances should be studied in experimental animals of three kinds: rodents of two species and non-rodents (Kocjumbas, 2006). In our experiment we continued to study the parameters of the acute toxicity of clathrochelate ferrum (IV) in rats and quail, which today are considered to be among the most beneficial and demonstrative models for experiments. As a result of the studies, it has been established that iron (IV) clathrochelate is non toxic to rats, in contrast to rodents of another species - white mice (Dukhnitsky et al., 2018).

For quails, the toxicity of the compounds of the iron (IV) has not been investigated to date. We have found for the first time that the average lethal dose of iron (IV) clathrochelate for internal administration in quails is $764 \pm 33 \mathrm{mg} / \mathrm{kg}$ of body weight. This study of the acute toxicity of iron (IV) clathrochelate, which has been recently developed in Ukraine, using laboratory animals concerns a drug of low toxicity (the 4th grade of toxicity State ST 12.1.007-76). Such data are consistent with the acute toxicity of white mice (Dukhnisky et al., 2018). It is intersting that clinical status of the birds of the groups II and III receiv- 
ing (iron (IV) clathrochelate at doses of 600 and $700 \mathrm{mg} / \mathrm{kg}$, respectively) was completely restored to normal on the 8-9th day, and in quail in groups IV-V receiving (iron (IV) clathrochelate at doses of 800 and 900 $\mathrm{mg} / \mathrm{kg}$, respectively) on the 14-15th day. This gives us the opportunity to assume that there is a functional cumulation of the iron (IV) as a representative of a group of heavy metals. To sum up the results of our research, we can assume that iron (IV) clathrochelate is a drug of low to nontoxicity to laboratory animals (birds).

\section{Conclusion}

The conducted research has established that iron (IV) clathrochelate is nontoxic to rats while the average lethal dose of clathrochelate of the investigated drug for internal administration in quails is $764.3 \pm$ $32.7 \mathrm{mg} / \mathrm{kg}$. According to the classification of chemicals by the degree of danger (State ST 12.1.007-76), iron (IV) clathrochelate complexes correspond to the third grade of hazard, and according to the classification of substances for toxicity they are classified as category 4 (low toxicity substances). The prospect of further research is to investigate the pharmacological and toxicological properties of (IV) iron (IV) clathrochelate for chronic toxicity.

\section{References}

Batrakov, A., Travkin, O., \& Jakovleva, E. (2005). Profilaktika alimentarnoj anemii u porosjat [Prevention of malignant anemia of piglets]. Veterinarija, 12, $44-45$ (in Russian).

Bonkovsky, S., \& Herbert, L. (1991). Iron and the liver. The American Journal of the Medical Sciences, 301(1), 32-43.

Broide, E., Reifen, R., Matalon, S., Berkovich, Z., \& Shirin, H. (2018). Expression of duodenal iron transporter proteins in diabetic patients with and without iron deficiency anemia. Journal of Diabetes Research, 6, 1-4.

Collins, J. (2002). TAML oxidant activators: A new approach to the activation of hydrogen peroxide for environmentally significant problems. Accounts of Chemical Research, 35(9), 782-790.

Commission of the European Communities: Council Directive of 18 December 1986 on the Lows, regulating the Application of Principles of Good Laboratory Practice and the Verification of Their Applications for Tests on Chemical Substances (87/18/EEC) (1991). The Rules Governing Medicinal Products in the European Community, 1, 145-146.

De la Cruz-Góngora, V., Villalpando, S., \& Shamah-Levy, T. (2018). Prevalence of anemia and consumption of iron-rich food groups in Mexican children and adolescents. Salud Pública de México, 60(3), 291-300.

Derkach, I. (2017). Suchasni tendencii' na vitchyznjanomu rynku ferumvmisnyh preparativ dlja tvaryn [Modern trends of the Ukrainian market of ironcontaining products for animals]. Naukovyj Visnyk L'vivs'kogo Nacional'nogo Universytetu Veterynarnoi' Medycyny ta Biotehnologij imeni S. Z. G'zhyc'kogo, 19(78), 23-25 (in Ukrainian).

Derkach, I., Derkach, S., \& Sotnichenko, I. (2018). Ferum u skladi kormovyh dobavok, gotovyh kormiv ta premiksiv na farmacevtychnomu rynku v Ukrai'ni [Iron in the content of feed additives, prepared feeds and premixes on the pharmaceutical market in Ukraine]. Naukovyj Visnyk L'vivs'kogo Nacional'nogo Universytetu Veterynarnoi' Medycyny ta Biotehnologij imeni S. Z. G'zhyc'kogo, 83, 290-294 (in Ukrainian).

Diel, J., Bertoldi, A., \& Pizzol, T. (2018). Iron salts and vitamins: Use, purchase and sources of obtainment among children in Brazil. Cad Saude Publica, 34(9), e00133317.

Dos Santos Vieira, D. A., Hermes Sales, C., Galvão Cesar, C. L., Marchioni, D. M., \& Fisberg, R. M. (2018). Influence of haem, non-haem, and total iron intake on metabolic syndrome and its components: A population-based study. Nutrients, 10(3), 314.

Dukhnitsky, V. B., Derkach, I. M., Plutenko, M. O., Fritsky, I. O., \& Derkach, S. S. (2018). Vyznachennja parametriv gostroi' toksychnosti ferumu (IV) na bilyh myshah [Determination of the accumulative toxicity parameters of iron (IV) on white mice]. Ukrainian Journal of Ecology, 8(2), 308-312 (in Ukrainian).

England, J., Bigelow, O., Katherine, M., Heuvelen, V., Farquhar, E., Martinho, M., Meier, K., Frisch, J., Münck, E., \& Que, L. (2014). An ultra-stable oxoiron (IV) complex and its blue conjugate base. Chemical Science, 5, 1204-1215.

Ganz, T. (2013). Systemic iron homeostasis. Physiological Reviews, 93(4), 1721-1741.

Geisser, P., Baer, M., \& Schaub, E. (1992). Structure/histotoxicity relationship of parenteral iron preparations. Arzneimittel for Schung, 42(12), 1439-1452.

Groves, J. T. (2006). High-valent iron in chemical and biological oxidations. Journal of Inorganic Biochemistry, 100(4), 434447.
Gutyj, B., Martyshchuk, T., Bushueva, I., Semeniv, B., Parchenko, V., Kaplaushenko, A., Magrelo, N., Hirkovyy, A., Musiy, L., \& Murska, S. (2017). Morphological and biochemical indicators of blood of rats poisoned by carbon tetrachloride and subject to action of liposomal preparation. Regulatory Mechanisms in Biosystems, 8(2), 304-309.

Jiefen, C., Yinping, L., Peng, Y., Qiping, Z., Jingfeng, W., Yongzhou, C., \& Peng, W. (2017). A novel low molecular weight Enteromorpha polysaccharideiron (III) complex and its effect on rats with iron deficiency anemia (IDA). International Journal of Biological Macromolecules, 108, 412-418.

Kalynovska, L. (2014). Zareyestrovani v Ukrayini preparaty dlya profilaktyky i likuvannya tvaryn pry anemiyi [Medicines which are registered in Ukraine for the prevention and treatment of animals with anemia]. Naukovo-Tehnichnyj Byuleten Instytutu Biologiyi Tvaryn i Derzhavnogo Naukovo-Doslidnogo Kontrolnogo Instytutu Vetpreparativ ta Kormovyh Dobavok, 15(1), 279-283 (in Ukrainian).

Killip, S., \& Bennett, M. (2008). Iron deficiency anemia. American Family Physician, 78(8), 671-678.

Kim, J. C., Wilcock, P., \& Bedford, M. R. (2018). Iron status of piglets and impact of phytase superdosing on iron physiology: A review. Animal Feed Science and Technology, 235, 8-14.

Kocjumbas, I. (2006). Doklinichni doslidzhennja veterynamyh likars'kyh zasobiv [Preclinical studies of veterinary medicinal products]. Triada Pljus, Lviv (in Ukrainian).

Kosenko, M. V., Malyk, O. G., \& Kocjumbas, I. J. (1997). Toksykologichnyj kontrol' novyh zasobiv zahystu tvaryn [Toxicological control of new animal protection means]. Kyiv (in Ukrainian).

Maes, D., Steyaert, M., Vanderhaeghe, C., López Rodríguez, A., de Jong, E., Del Pozo Sacristán, R., Vangroenweghe, F., \& Dewulf, J. (2011). Comparison of oral versus parenteral iron supplementation on the health and productivity of piglets. Veterinary Record, 19, 168-188.

Meier, T., Schropp, P., Pater, C., Leoni, A., Khov-Tran, V., \& Elford, P. (2011). Physicochemical and toxicological characterization of a new generic iron sucrose preparation. Arzneimittelforschung, 61(2), 112-119.

Miranda, M., \& Lawson, H. (2018). Ironing out the details: Untangling dietary iron and genetic background in diabetes. Nutrients, 10(10), 1-9.

Peña-Rosas, J., De-Regil, L., Gomez Malave, H., Flores-Urrutia, M., \& Dowswell, T. (2015). Intermittent oral iron supplementation during pregnancy. Cochrane Database System Review, 19(10), 1-9.

Pillay, D., Wham, C., Moyes, S., Muru-Lanning, M., The, R., \& Kerse, N. (2018). Intakes, adequacy, and biomarker status of iron, folate, and vitamin $\mathrm{B}_{12}$ in māori and non-māori octogenarians: Life and living in advanced age: A cohort study in New Zealand (LiLACS NZ). Nutrients, 10(8), 1-9.

Stefanyk, V. Y., Stravskyy, Y. S., \& Kobyliukh, I. B. (2017). Supozytorii' iz vmistom nanochastynok ferumu v korekcii' antyoksydantnogo zahystu organizmu koriv pislja otelu [Superpositions with nanoparticles of the ferum in the correction of the antioxidant protection of the organism of cows after calving]. NV LNU Veterynarnoji Medycyny ta Biotehnologij, Serija Veterynarni Nauky, 82, 201-204 (in Ukrainian).

Streyl, K., Carlstron, J., Dantos, E., Mendoza, R., Islas, J., \& Bhushan, C. (2015). Field evaluation of the effectiveness of an oral toltrazuril and iron combination (baycox ${ }^{\circledR}$ iron) in maintaining weaning weight by preventing coccidiosis and anaemia in neonatal piglets. Parasitol Research, 114(1), 193-200.

Tang, L. L., Gunderson, W. A., Weitz, A. C., Hendrich, M. P., Ryabov, A. D., \& Collins, T. J. (2015). Activation of dioxygen by a TAML activator in reverse micelles: Characterization of an FeIII FeIV dimer and associated catalytic chemistry. Journal American Chemical Society, 137(30), 9704-9715.

Tang, L. L., Ryabov, A. D., \& Collins, T. J. (2016). Kinetic evidence for reactive Dimeric TAML iron species in the catalytic oxidation of nadh and a dye by $\mathrm{O}_{2}$ in aot reverse micelles. American Chemical Society Catalysis, 6(6), 3713-3718.

Terpilowska, S., \& Siwicki, A. (2018). Interactions between chromium (III) and iron (III), molybdenum (III) or nickel (II). Cytotoxicity, genotoxicity and mutagenicity studies. Chemosphere, 201, 780-789.

Terpilowska, S., \& Siwicki, A. (2019). Pro- and antioxidant activity of chromium (III), iron (III), molybdenum (III) or nickel (II) and their mixtures. Chemical Biolical Interaction, 298, 43-51.

Todoriuk, V. B., Hunchak, V. M., Gutyj, B. V., Gufriy, D. F., Hariv, I. I., Khomyk, R. I., \& Vasivhttps, R. O. (2018). Preclinical research of the experimental preparation "Ferosel T'. Ukrainian Journal of Veterinary and Agricultural Sciences, 1, 3-9.

Tomyn, S., Shylin, S., Bykov, D., Ksenofontov, V., Gumienna-Kontecka, E., Bon, V., \& Fritsky, I. (2017). Indefinitely stable iron (IV) cage complexes formed in water by air oxidation. Nature Communications, 8, 1-8.

Vrednye veshhestva. Klassifikacija i obshhie trebovanija bezopasnosti. GOST 12.1.007-76 (1982) [Classification and general safety requirements. State ST 12.1.007-76]. Izdatel'stvo Standartov, Moscow (in Russian).

Walter, T., Olivares, M., Pizarro, F., \& Muñoz, C. (1997). Iron, anemia, and infection. Nutrition Reviews, 55(4), 111-124. 